




\section{Daftar lsi}

KATA PENGANTAR iv

SAMBUTAN PANITIA $\mathbf{v}$

KERANGKA ACUAN SEMINAR DAN LOKAKARYA TEOLOGI FEMINIS ix

SEBUAH DRAFT: Mengarus-utama-kan Teologi Feminis

Kristen-Indonesia dalam Pendidikan Teologi Kristen, Gereja, dan

Masyarakat Indonesia

1

Teologi Feminis: Sebuah Perspektif Laki-Laki

TEOLOGI FEMINIS DI INDONESIA :Upaya Menjejaki

Perkembangannya $\mathbf{3 7}$

Teologi Feminis di Fakultas Teologi UKIT Tahun 1991/1992 - 2013

51

Tonggak-Tonggak Gerakan Feminis dan Inisiatif Tologi Feminis di Asia \& Indonesia $\mathbf{6 7}$

Pendekatan Historis terhadap Wacana dan Perkembangan Teologi Feminis di Indonesia $\mathbf{8 1}$

Agustina Lumentut dan Perubahan Sosial di Sulawesi Tengah 89

Tranformasi Pela dan Kristologi demi Kebersamaan Hidup di Maluku 99

LITURGI FEMINIS: Liturgi yang Merangkul 
TRAGEDI '65 di NUSA TENGGARA TIMUR Makna dan Dampaknya dalam Pandangan Perempuan Korban 129

Pengembangan Wacana Teologi Feminis di Ranah Gereja

Wacana Teologi Feminis di GKP 143

Pembebasan dan Transformasi Perempuan (Pelayanan

Pendampingan Women Crisis Center GKPS “Sopou Damei” terhadap Perempuan Korban Kekerasan di Wilayah Siantar - Simalungun) 153

Peta Pemikiran dan Perkembangan Teologi Feminis di Indonesia 171

PEMETAAN: Usul untuk sebuah alat bantu Perspektif seorang anggota pengurus PERSETIA

177

DOING THEOLOGY AS ASIAN WOMEN: tinjauan oleh John C. England dkk., dalam Asian Christian Theologies - a research guide to authors, movements, sources $\mathbf{1 8 1}$

Lokakarya I 185

Lokakarya 2191

Lokakarya 3201

Silabus-silabus $\quad 209$

Jadwal Semiloka Teologi Feminis $2013 \quad 223$

DAFTAR REGISTRASI PESERTA SEMILOKA TEOLOGI FEMINIS

WISMA SAMADI, KLENDER, JAKARTA, 17 - 20 JULI 2013 


\section{Tranformasi Pela dan Kristologi demi Kebersamaan Hidup di Maluku}

(Suatu Kajian Misiologi)

Dr. Rachel Iwamony

\section{Realitas Beragama dan Berbudaya di Maluku: Realitas 'Dualistik'}

$\int \begin{aligned} & \text { alah satu sistem budaya orang Maluku yang khas adalah } \\ & \text { budaya Pela. Pela merupakan suatu sistem budaya yang } \\ & \text { menunjukkan hubungan persaudaraan yang khusus, }\end{aligned}$ sebagai kakak-adik, antara dua atau tiga negri (desa). Hubungan persaudaraan ini menuntut tanggungjawab antara negri-negri yang memiliki relasi pela, antara lain, mereka harus saling menjaga atau melindungi, serta tidak boleh ada pernikahan diantara mereka. Budaya pela mempengaruhi dan membentuk kehidupan yang unik dari masyarakat pendukungnya. Keunikan itu nampak antara lain dalam kehidupan keagamaan mereka. Sekalipun mereka yang memiliki hubungan pela adalah penganut agama yang berbeda, mereka tetap saling melindungi di saat konflik sosial di Maluku tahun 1999 - 2004. Mekipun demikian, kenyataan yang positif tersebut tidak dapat menutupi salah satu kelemahan budaya pela, yaitu pela hanya berfungsi bagi para pendukungnya. Nilai-nilai positif pela tidak dirasakan oleh orang lain, yaitu mereka yang tidak memiliki hubungan pela itu. Contohnya, pada saat konflik, orang 
Batu Merah hanya melindungi orang Passo asli yang adalah adi pe (adik pela) mereka; demikian juga sebaliknya orang Passo terhadap orang Batu Merah, kaka pe (kakak pela) mereka. Kenyataan inilah yang mendorong kesadaran akan kebutuhan memahami budaya pela secara baru. Salah satu pendekatan memahami pela secara baru adalah melalui pendekatan teologis.

Studi secara teologis terhadap pela sebagai satu sistem budaya di Maluku merupakan sebuah kebutuhan mendasar sebab dalam jangka waktu yang cukup lama, gereja memiliki pandangan negatif terhadap budaya lokal. Akibatnya, nilai-nilai positif pela yang antara lain membangun relasi keagamaan yang khas dan positif antar-umat beragama, tidak dapat dikembangkan oleh orang Kristen Maluku (maupun orang Islam Maluku) sebagai cara hidup Kristiani. Menurut sebagian orang Maluku, penganut agama Islam dan Kristen Maluku membangun relasi yang baik hanya ketika mereka menempatkan diri sebagai orang Maluku; tidak sebagai orang yang beragama. Agama dinilai tidak memberi kontribusi positif dalam membangun relasi antarumat beragama. Wujud dari pandangan itu adalah kecenderungan untuk membuat perbedaan antara menjadi orang Maluku dan menjadi orang Maluku yang beragama Islam atau Kristen. Pandangan dualistik muncul di sini. Tidak ada upaya mengintegrasikan nilai-nilai budaya lokal sebagai bagian dari nilai-nilai agama. Oleh karena itu, transformasi teologis sangat diperlukan untuk menemukan perspektif baru dalam melihat hubungan budaya dan agama, sehingga mendorong orang Maluku memahami budaya pela secara baru, agar orang Maluku pertama-tama, dapat meningkatkan hubungan positif antar umat beragama dan kedua, pela dapat terbuka kepada 'orang luar' (outsiders).

Pandangan yang menganggap bahwa budaya lebih mengarahkan penganut agama Islam dan Kristen untuk hidup berdampingan secara lebih baik dibandingkan dengan agama, merupakan kritik terhadap agama-agama. Umat beragama perlu melakukan evaluasi dan krtitik diri terhadap pemahaman mereka tentang eksistensi agama-agama itu, antara lain terhadap ajaran masing-masing agama. Dari sisi agama Kristen, salah satu ajaran 
yang perlu dievaluasi adalah ajaran tentang Yesus Kristus atau Kristologi sebab pemahaman tentang siapa itu Yesus Kristus sangat mempengaruhi sikap orang Kristen dalam membangun kebersamaan hidup dengan agama-agama lain. Pandangan bahwa Yesus hanya menyelamatkan orang Kristen bersumber pada pemahaman yang sempit tentang Yesus Kristus. Kedua hal inilah yang akan dibahas dalam tulisan ini.

\section{Injil dan Kebudayan}

Yang saya maksudkan dengan kebudayaan di sini adalah seluruh pandangan dunia, norma, nilai dan kebiaasaan atau adat-istiadat yang membentuk kehidupan manusia secara khusus dalam waktu dan tempat atau lingkungan tertentu.

Budaya tidak saja memiliki aspek-aspek positif. Ada juga aspek-aspek negatif dalam kebudayaan. Oleh karena itu, dalam rangka memahami secara baik suatu kebudayaan, kebudayaan itu harus dipelajari secara kritis. Ada 3 (tiga) paradigma yang mewarnai realitas kebudayaan. Pertama, budaya yang memiliki nilai-nilai maupun kebiasaan yang berpadanan dengan nilainilai Injil. Artinya, ada budaya yang memiliki nilai-nilai yang sama dengan nilai-nilai yang dibawah oleh Injil. Contohnya di Maluku, pemeliharaan alam melalui budaya sasi. Kedua, budaya yang nilai-nilainya tidak bertentangan dengan Injil tetapi hanya bermanfaat bagi masyarakat pemilik budaya itu. Contohnya, relasi persaudaraan yang dibangun oleh budaya pela memiliki nilai Injili, tetapi nilai-nilai itu hanya terbatas pada masyarakat yang terhubung ikatan pela itu. Ketiga, nilai-nilai dan kebiasaan yang ada dalam satu budaya yang menginspirasi masyarakat untuk melakukan hal-hal yang membahayakan hidup manusia. Contohnya, pada masa-masa awal budaya pela, pembentukan ikatan pela, terutama untuk menghentikan pertempuran atau perkelahian yang terjadi, ditandai dengan mengorbankan seorang manusia. Contoh lainnya di zaman sekarang adalah pemerkosaan hak-hak asasi manusia dan pelecehan terhadap kaum perempuan. Tiga contoh budaya yang dicatat terakhir adalah contoh-contoh budaya yang bertentangan dengan injil. 
Tiga paradigma kebudayaan yang dicatat di atas menunjukkan bahwa pergumulan untuk menentukan sikap kritis terhadap hubungan injil dan kebudayaan bukanlah merupakan persoalan yang mudah. Diperlukan keseriusan dan kekritisan yang tinggi dalam mempelajari hubungan itu. Salah satu studi yang cukup penting dalam hal ini adalah pandangan klasik dari Richard Niebuhr.

Richard Niebuhr mencatat lima tipe sikap gereja dalam melihat kebudayaan. Dari kelima tipe tersebut, secara umum, tipe kelima "Kristus mentransformasi kebudayaan" menjadi favorit banyak orang. Meskipun demikian, jika dilihat secara kritis, maka tipe kelima ini juga memiliki kelemahan. Kelemahan inilah yang dikemukakan oleh John Howard Yoder bahwa "Jika ada kritik terhadap tipe kelima, maka kritik itu hendak menantang Niebuhr untuk memberi perhatian terhadap kriteria transformasi. "Mentransformasi" berarti mengganti bentuk dari sesuatu menurut standard tertentu. Oleh karena itu, kita mesti memiliki gambaran "sebelum" dan "sesudah" bagaimana Kristus mentransformasi suatu kebudayaan." Dalam hal ini, Yoder menegaskan perlunya kriteria dan standar bagi transformasi kebudayaan. Kebutuhan yang dicatat Yoder dijawab oleh Martin Brinkman. Menurut Brinkman "tidak ada kriteria yang dapat dikemukakan tanpa merujuk kepada peran Kitab Suci dalam persekutuan umat, sebab isi Kitab Suci selalu memiliki fungsi sebagai titik pusat identitas suatu tradisi keagamaan."

Jika dilihat secara lebih mendalam tipe kelima dari Niebuhr, maka ada beberapa catatan kritis yang perlu dikemukakan. Pertama, sekalipun Niebuhr menolong untuk memunculkan tipe transformasi sebagai tipe ideal, tipe ini masih terbatas pada satu arah proses transformasi. Tipe kelima memiliki kekurangan, terutama ketika kita mengakui adanya nilai-nilai positif dari suatu kebudayaan. Kedua, dengan mengakui nilai-nilai positif suatu kebudayaan, kita terbuka terhadap suatu kemungkinan bahwa suatu kebudayaan dapat memberikan kontribusi yang positif untuk mengerti injil secara kontekstual dalam setiap konteks. Jadi, tranformasi tidak hanya berarti injil harus mentranformasi suatu 
kebudayaan, tetapi juga dapat terjadi bahwa suatu kebudayaan dapat mentransformasi konsep injil yang diberitakan gereja. Pendekatan nilah yang disebut double transformation atau transformasi ganda.

Pendekatan double transformation ini memiliki prinsip bahwa setiap budaya manusia memiliki nilai-nilai positif yang merupakan indikasi bahwa Kristus sudah berkarya dalam setiap kebudayaan dan karyaNya itu berlangsung dalam cara-cara yang misterius. Dalam situasi ini, tugas gereja adalah menolong orang Kristen untuk menemukan kehadiran Kristus yang aktif dalam kehidupan mereka. Jadi, pendekatan double transformation menegaskan prinsip bahwa kita tidak dapat hanya mengerti transformasi dalam artian bagaimana injil secara total mengubah atau mempengaruhi budaya, tetapi juga bagaimana suatu kebudayaan menawarkan suatu perspektif yang baru dalam memahami injil. Dalam double transformation, budaya menantang dan mempengaruhi injil dan injil menantang dan mempengaruhi kebudayaan. Pendekatan ini merupakan suatu pendekatan yang dapat menolong gereja untuk membangun perjumpaan dialektis yang kritis dan kreatif antara kebudayaan dengan iman dan kesaksian gereja.

\section{Kristus yang Disalib: Dasar Transformasi}

Berdasarkan dukungan terhadap pandangan bahwa dibutuhkan standar bagi suatu tranformasi terhadap kebudayaan, maka dalam rangka mengembangan pemikiran teologis terhadap kemungkinan mentranformasi budaya pela demi memperluas nilai-nilai positifnya, maka pandangan teologis yang dgunakan sebagai standard adalah Kristus yang Tersalib. Salah satu alasan mendasar dari pilihan ini adalah bahwa dalam budaya pela aspek pengorbanan adalah salah satu elemen penting pembentukan hubungan pela. Pengorbanan menempatkan budaya pela sebagai sesuatu yang sangat sakral dalam hidup masyarakat Maluku. Secara mendasar, dalam membangun pemikiran tentang proses transfromasi teologis ini, saya berusaha untuk memahami budaya pela sebagai seorang Kristen yang percaya kepada Kristus yang 
Disalibkan tetapi juga memahami Kristus yang Disalibkan sebagai seorang Maluku. Diharapkan perspektif ini membawa perubahan pada pemahaman orang Kristen Maluku tentang pela dan Kristus yang Tersalib.

Pemahaman tentang Kristus yang Disalib menegaskan beberapa nilai penting, tetapi demi menemukan standard transformasi, kita hanya memberi perhatian pada 2 aspek, yaitu: Pengorbanan dan Perjanjian (Covenant) yang Baru.

Pengorbanan Kristus menawarkan banyak nilai penting untuk hidup manusia. Miroslav Volf mencatat bahwa "Kristus mempersatukan orang-orang yang berbeda dalam satu tubuh... Ia melakukan itu melalui penderitaannya. Oleh karena itu, adalah sangat penting ketika Ellen Carry menulis bahwa orang Yahudi dan orang kafir dijadikan satu tubuh anak-anak Allah tanpa mempertimbangkan masalah etnis, nasional, gender, ras dan klas sosial... Salib adalah kenyataan penyerahan diri sendiri dari satu orang kepada banyak orang (self-giving of the one for many)." Berdasar pada pandangannya ini, maka dapatlah dimengerti sikap Volf untuk menghubungkan salib Kristus sebagai titik pandangan teologi dalam merangkul 'orang lain' (others). Ia menegaskan sikap teologisnya dengan mengatakan:

Pada pusat salib keinginan Kristus untuk tidak membiarkan orang lain tetap menjadi musuh dan menciptakan ruang dalam dirinya sendiri untuk membiarkan orang lain masuk.... Ini adalah konsekwensi dari kehendak Allah untuk menghancurkan kekuatan permusuhan yang ada dalam hidup manusia tanpa kekerasan, dan menerima manusia masuk ke dalam persekutuan dengan Allah. Tangan yang terbuka di salib adalah tanda dari ruang yang Allah ciptakan dan undangan Allah kepada musuh untuk masuk.

Volf memberi arti kepada tangan Tuhan yang terbuka di salib sebagai tanda 'merangkul'. Melalui salib, Allah membuka tanganNya untuk memperbaiki dan membangun hubungan dengan manusia; terhadap tindakannya ini, Allah membiarkan manusia bebas meresponsnya. Ide penting yang muncul di sini adalah bahwa merangkul adalah sebuah tindakan yang menuntut kemauan dari dua pihak untuk bertemu satu dengan yang lain. Selain itu, 
selalu dibutuhkan kemauan untuk menciptakan kemungkinan saling merangkul. Di sini, perhatian Volf ada pada pengaruh yang mendasar dari salib terhadap seluruh bentuk keterpisahan dan keterasingan (alienation). Pemikiran yang dikemukakan Volf sangat menarik karena ia mengembangkan pemikiran teologisnya berdasarkan pengalamannya sendiri sebagai seorang Kroasia yang mengalami konflik.

Salib Kristus juga menawarkan suatu pandangan teologis yang penting bahwa pengorbanan Kristus merupakan tantangan bagi manusia untuk berbagi hidup dengan orang lain. Oleh karena itu, Volf menekankan prinsip rekonsiliasi dalam pengorbanan Kristus. Ini menunjukkan pula gagasannya bahwa tanpa pengorbanan, tidak akan ada rekonsiliasi dalam hidup manusia. Rekonsiliasi sebagai implikasi dari pengorbanan Kristus berkaitan erat dengan pembaruan hubungan manusia dengan Allah. Allah dalam Kristus menghapus keterasingan atau keterpisahan (alienation). Allah dalam Kristus adalah jembatan hidup yang mempertemukan semua yang hidup. Menurut James Dunn, Allah secara aktif membangun rekonsiliasi dengan dan dalam hidup manusia. Dalam hal ini, bagi Dunn Allah adalah inisiator dari rekonsiliasi Allah dengan manusia dan sumber inspirasi bagi rekonsiliasi antar-manusia.

Selain aspek Pengorbanan, Covenant yang Baru adalah juga salah satu konsep yang perlu dibicarakan karena ide Kristus yang Disalib menekankan pula hal ini. Banyak teolog yang melakukan studi terhadap pemikiran teologi Paulus mencatat bahwa Covenant yang Baru adalah reaksi Paulus terhadap Tora. Paulus menggambarkan 'perjanjian yang baru' itu sebagai suatu hubungan yang baru yang diciptakan Allah melalui pengorbanan Yesus. Allah sendiri telah menciptakan cara baru untuk bertemu Dia. Allah tidak hanya tergantung pada perjanjian yang dibuat dengan Israel. Tegasnya, melalui peristiwa Kristus, Allah membuat suatu kemungkinan lain untuk bertemu Dia; jadi tidak hanya melalui Tora. Pertanyaan penting disini adalah apakah ini berarti Paulus meninggalkan Tora? Bagaimana dengan konsep Israel sebagai bangsa pilihan Allah? 
Suatu gagasan yang dapat dikemukakan berkaitan dengan pertanyaan di atas adalah bahwa Paulus tidak menentang Tora. Paulus juga tidak menyangkali fungsi Tora. Ia hanya berupaya untuk melihat Tora dalam kerangka pengorbanan Kristus, yang telah memenuhi segala tuntutan Tora. Dalam perspektif ini, kita dapat mengerti mengapa Wright melihat pengorbanan Kristus sebagai klimaks perjanjian. Paulus menekankan aspek ini, khususnya ketika dia berbicara tentang tempat bangsa lain atau orang kafir dalam perjanjian Allah dengan Israel. Di dalam Tora, Allah kurang memberi perhatian terhadap bangsa lain sebab Tora sebagai simbol perjanjian Allah hanya bermanfaat bagi Israel, bangsa pilihan itu. Karena sifatnya yang demikian, Tet-Lim Yee, seorang teolog lain mengatakan bahwa perjanjian Allah dengan Israel melalui Tora cenderung membuat perbedaan antara Israel dengan bangsa lain. Oleh karena itu, pemenuhan tuntutan Tora merupakan suatu keharusan bagi Israel. Hal ini nampak dalam hal penekanan terhadap sunat. Yee mengatakan bahwa bagi orang Yahudi sunat adalah tanda pemilihan yang dulu (hingga sekarang) merupakan akta pertama pemenuhan kewajiban dan keanggotaan dari perjanjian itu. Bagi Yee, dalam teologi Paulus, Kristus yang Disalib adalah pribadi yang telah menghancurkan perbedaan antara Yahudi dan non Yahudi. Kristus adalah jembatan pertemuan Yahudi non Yahudi sebab melalui Dia tidak ada lagi diskriminasi, termasuk diskriminasi agama.

Kristus dilihat sebagai mediator perdamaian. Kristus menghendaki perdamaian dengan mengakhiri keterasingan antara orang Yahudi dengan orang kafir. Kristus mempersatukan Yahudi dan non Yahudi bukan karena perbedaan antara Yahudi dan non Yahudi sebagai dua kelompok suku telah dihilangkan, tetapi karena identitas Yahudi telah menjadi terlalu membingungkan. Bahwa identitas ini telah menjadi tembok yang memisahkan dan membedakan Yahudi dari umat manusia lainnya di dunia. Dalam hal ini, Yee mengemukakan pemikiran bahwa oleh Kristus, orang Yahudi dan non Yahudi dibawa dalam suatu hubungan yang baru dan lain, yaitu rekonsiliasi. Rekonsiliasi yang dibawah oleh Kristus adalah rekonsiliasi yang mendorong orang Yahudi untuk 
keluar dari ketertutupan agar bertemu dengan orang non Yahudi dalam hubungan setara. Jadi, dalam hal ini, rekonsiliasi mendorong ketulusan hati dari setiap orang masuk menjadi bagian dari orang lain dan setiap orang diharapkan untuk selalu mengidentifikasikan diri dengan orang lain. Intinya, rekonsiliasi seperti ini menuntut setiap orang untuk melihat dalam dirinya eksistensi 'orang lain'.

Perjumpaan Kreatif konsep Kristus yang Disalib dengan konsep pela Ada tiga (3) hal penting yang akan menjadi pokok pembahasan pada bagian ini, yaitu:

a). Transformasi Yesus sebagai Tete Manis

b). Transformasi pela sebagai pengorbanan

c). Transformasi pela sebagai perjanjian

\section{a) Transformasi Yesus sebagai Tete Manis}

Faktor utama yang mendorong orang Maluku untuk tetap memelihara budaya pela adalah keterikatan dengan leluhur mereka. Leluhur orang Maluku memiliki tempat khusus dalam falsafah hidup orang Maluku. Sekalipun kekristenan sudah ada di Maluku lebih dari 450 tahun, iman kepada Yesus Kristus tidak mengubah pandangan orang Maluku tentang leluhur mereka. Ada dua alasan utama orang Maluku tetap menjaga budaya pela. Pertama, untuk menunjukkan ketaatan mereka kepada leluhur. Kedua, untuk menghindari hukuman dari leluhur. Dalam menghidupi budaya pela, alasan kedua lebih menonjol dibanding alasan pertama. Di sini, nampak jelas bahwa leluhur dilihat sebagai hakim yang akan menghukum setiap orang dan komunitas yang tidak hidup sesuai tututan budaya pela.

Dalam rangka melakukan transfromasi teologis terhadap budaya pela, diperlukan konsep atau ide yang menolong orang Maluku untuk melihat secara baru fungsi leluhur mereka dalam budaya pela. Menurut Damamain "Dalam rangka memberikan tempat bagi tete-nene moyang, peran mereka sebagai penjaga adat harus ditekankan. Oleh karena itu, leluhur orang Maluku dapat disamakan dengan Musa yang menerima Tora bagi bangsa Israel. 
Leluhur orang Maluku dapat mewariskan adat sebab mereka menerima inspirasi mendalam dari Upu Lanite atau Uplero. Dalam perspektif ini, orang Maluku dapat tetap menghormati leluhur mereka sebagai mediator, tetapi tidak disembah sebagai Tuhan." Dengan menempatkan leluhur sebagai mediator, orang Maluku mengakui bahwa mereka hanya percaya kepada Tuhan. Jadi, ketika orang Maluku melihat leluhur mereka hanya sebagai mediator yang menciptakan budaya pela, karena mereka menerima inspirasi dari Tuhan, yang mereka kenal dengan nama tete manis, orang Maluku tidak akan jatuh ke dalam kecendrungan mengganti Tuhan dengan leluhur mereka. Melihat leluhur hanya sebagai mediator adalah juga sebuah konsep baru yang ditawarkan oleh Kristus yang Disalib.

Sangat menarik bahwa oleh karena keterikatan dengan leluhur, orang Maluku menyebut Yesus Kristus sebagai Tete Manis. Sebutan Tete Manis menegaskan pengalaman iman orang Maluku dengan Yesus Kristus. Dia adalah Tuhan yang tidak hidup jauh dari manusia. Sama seperti tete-nene yang tidak hanya memiliki kekuasaan dan kewibawaan dalam suatu keluarga, tetapi juga hidup bersama keluarga, mencintai keluarga dan selalu menjadi penasehat yang bijaksana dalam keluarga, Yesus Kristus mencintai dan hidup bersama orang Maluku, memiliki kekuasaan dan kewibawaan dalam hidup orang Maluku. Dengan menyebut Yesus sebagai Tete Manis, konsep Yesus ditranformasi kedalam figure yang sangat penting dalam budaya orang Maluku. Sekalipun demikian, perlu ditegaskan bahwa tentu saja Yesus adalah Tete Manis tetapi bukan saja hanya sebagai Tete Manis.

Hal penting yang ditemukan di sini adalah bahwa setiap orang dengan budayanya memberi nama kepada Yesus Kristus, tetapi Yesus Kristus sendiri juga memperkenalkan hal-hal yang baru terhadap suatu kebudayaan. Tentu saja nama baru yang diberikan kepada Yesus Kristus harus memiliki makna khusus bagi masyarakat penganut budaya tersebut. Dengan menggunakan sebutan 'khusus' kepada Yesus, suatu kelompok masyarakat mendekatkan Yesus Kristus kepada mereka, sehingga Yesus Kristus tidak menjadi sosok yang hanya diimani tetapi juga dialami dalam kehidupan nyata sehari-hari mereka. Sebutan kepada Yesus 
merupakan upaya orang-orang Kristen untuk menggambarkan siapa itu sosok Yesus Kristus bagi mereka. Oleh karena itu, sebutansebutan kepada Yesus selalu memiliki dua dimensi, yaitu dimensi lokal dan dimensi universal. Yang dimaksudkan dengan dimensi lokal adalah konsep yang menyertai suatu sebutan yang maknanya hanya dimengerti oleh suatu kelompok masyarakat tertentu berdasarkan konteks budayanya; sedangkan dimensi universal adalah gambaran yang sangat mendasar tentang sosok Yesus yang dimengerti secara umum oleh semua orang Kristen tanpa dibatasi lokasi dan waktu. Salah satu contoh dimensi universal itu adalah pengakuan bahwa Yesus Kristus adalah Tuhan yang mengasihi dan berkarya menyelamatkan manusia.

Kristus yang Disalib adalah mediator yang membawa Allah dalam perjumpaan dengan manusia. Pengakuan ini menegaskan bahwa Yesus Kristus menghendaki rekonsiliasi dalam hidup manusia dan alam ciptaan, serta mengundang manusia untuk menjadi agen rekonsiliasi. Dengan menciptakan budaya pela sebagai sarana rekonsiliasi dalam hidup masyarakat, leluhur orang Maluku telah terlibat dalam undangan untuk menjadi agen rekonsiliasi. Menjadikan pela sebagai suatu sistem rekonsiliasi menunjukkan kesadaran leluhur orang Maluku akan keadaan keterasingan dan permusuhan dalam hidup masyarakat Maluku. Jadi, leluhur orang Maluku dapat dilihat sebagai mediator sebab mereka mampu merespons undangan yang diberikan oleh Kristus yang Disalib untuk mengambil bagian dalam upayaupaya rekonsiliasi dengan jalan membangun hubungan pela dan menerukan budaya pela itu bagi anak-cucu.

Dari prinsip ini, mewarisi budaya pela berarti tetap memelihara spirit pela yang mendorong orang Maluku untuk berani keluar dari lingkaran negri dan agama untuk bertemu sebagai sodara dengan orang dari negri dan agama lain. Sebaliknya, kecenderungan untuk menjaga dan memelihara budaya pela hanya sebagai repetisi peristiwa masa lampau menunjukkan pengingkaran yang dilakukan anak-cucu terhadap hakikat pela yang dibangun para leluhur. Bagi saya, sikap terakhir ini menunjukkan ketidaktaatan orang Maluku kepada leluhur mereka yang membangun budaya pela sebagai 
sarana rekonsiliasi mengatasi keterasingan dalam hidup.

Posisi leluhur sebagai mediator menolong orang Maluku untuk mentransformasi pemikiran mereka bahwa leluhur menghukum orang yang tidak hidup sesuai ketentuan-ketentuan budaya pela. Sebagai mediator, leluhur hanya melakukan kehendak Tuhan, sang Tete Manis. Sebagai manusia, leluhur orang Maluku tidak memiliki kekuasaan untuk mengendalikan hidup manusia dan menghukum mereka. Hukuman kepada manusia tidak berada dalam kewenangan dan kekuasaan para leluhur tetapi dalam tangan Tuhan, Tete Manis itu. Sekalipun demikian, oleh karena Yesus Kristus berkorban untuk menyelamatkan hidup manusia dan dunianya, maka pandangan bahwa penghukuman merupakan satu-satunya cara yang diberikan kepada mereka yang melanggar kehendaknya, termasuk budaya pela masih harus dikritisi dan dipertanyakan. Oleh karena itu, adalah baik jika dikembangkan pemikiran bahwa sebagai mediator, leluhur orang Maluku menghedaki kesejahteraan hidup anak-cucu mereka. Jadi, mengalami kesakitan dan kegagagalan dalam hidup dan pekerjaan semestinya tidak dilihat sebagai hukuman dari para leluhur.

\section{b) Transformasi pela sebagai pengorbanan}

Salah satu sifat ikatan pela adalah kategori insiders versus outsiders. Oleh karena itu, di sini konsep pengorbanan Kristus yang menghancurkan segala bentuk tembok pemisah antar manusia perlu dibicarakan. Pengorbanan Kristus menegaskan pemahaman bahwa orang Kristen Maluku harus terbuka untuk melewati tembok-tembuk budaya yang memisahkan. Menurut Hendriks "Yesus tidak menyesuaikan diri dengan norma yang diterima masyarakat di mana Dia hidup, tetapi bergerak keluar dan melakukan persahabatan dengan semua orang dari seluruh lapisan masyarakat, termasuk mereka yang termarginalisasi. Jadi, dalam iman Kristiani Yesus dilihat sebagai seseorang yang mampu melewati tembok-tembok pemisah, baik tembok budaya maupun agama untuk bertemu dengan orang yang berbeda etnis dan agama. Ini sisi penting dari nilai memberikan diri sendiri untuk kehidupan orang lain. Dalam hal ini, setiap orang dituntut 
proaktif bertemu dengan 'orang lain' atau the other, yang dalam kekuatannya sendiri tidak mampu untuk menciptakan hubungan yang sederajat. Berdasarkan pandangan ini, maka salah satu inti penting dari panggilan iman Kristen adalah tanggungjawab untuk menolong manusia keluar dari pola-pola hidup yang dibangun dalam keterpisahan.

Dalam persepktif Kristus yang Disalib, 'the other' adalah setiap orang yang berasal dari etnis, bangsa, dan agama lain. Iman kepada Yesus Kristus seharusnya mengarahkan prinsip hidup orang Kristen untuk membangun hidup dalam kesadaran bahwa kenyataan hidup bermasyarakat bahwa ada yang menjadi ciri yang membedakan manusia oleh karena perbedaan budaya, agama, jenis kelamin, pandangan politik, tidak dapat dijadikan alasan untuk membuat pemisahan dan diskriminasi dalam hidup manusia. Perbedaan-perbedaan tersebut menunjukkan kekayaan hidup manusia yang akan selalu menjadi salah satu faktor pembangkit dan pendorong pengakuan manusia bahwa manusia hidup dalam keterhubungan satu dengan yang lain. Pada taraf kesadaran iman atau kesadaran spiritual, perbedaan-perbedaan itu pada satu sisi, merefleksikan kemahakuasaan sang Pencipta dan pada sisi yang lain merefleksikan keterbatasan manusia. Oleh karena itu, setiap manusia membutuhkan orang lain dengan segala perbedaan yang dimilikinya. Supaya setiap orang memiliki kemauan untuk memberi hidupnya bagi orang lain, pengakuan bahwa orang lain menduduki posisi yang sama penting dengan diri sendiri mesti menjadi nilai hidup manusia. Hall menegaskan pandangan seperti ini bahwa "untuk memiliki kebaikan, secara mendasar, adalah untuk mengatasi segala bentuk subjek dan objek yang membuat pemisahan dalam hidup. Kebaikan itu adalah menderita dengan orang lain. Bukan sekedar untuk menunjukkan perasaan mengasihi seseorang. Tetapi lebih berarti menjadi dipercaya untuk masuk dalam solidaritas dengan orang lain, untuk mengalami apa yang dialami oleh orang lain".

Memberi hidup sendiri kepada orang lain sebagai tanda dari pengorbanan sebagaimana yang dilakukan oleh leluhur orang Maluku, dilakukan oleh lebih dari satu orang. Sedangkan 
di salib, Kristus yang Disalib bertindak sendirian. Realitas ini memberi implikasi yang sangat penting dalam memahami dan melakukan proses rekonsiliasi. Pendekatan transformasi ganda atau double transformation membantu kita untuk menemukan bahwa pengorbanan demi menciptakan rekonsiliasi dalam hidup mesti dilakukan secara proaktif oleh setiap individu sebagai bagian penting dari suatu masyarakat. Dari perspektif pengorbanan Kristus, kita melihat bahwa setiap individu memiliki tanggung jawab melakukan rekonsiliasi dalam hidup. Oleh karena itu, pela sebagai satu sarana rekonsiliasi dapat dilakukan oleh suatu komunitas tetapi juga dapat dilakukan oleh orang per orang.

Berdasarkan konsep-konsep yang telah dibahas di atas, dapat dikatakan bahwa dalam perspektif pengorbanan Kristus, pola pikir 'we versus them' yang ada dalam budaya pela, dapat diubah menjadi 'we in connection and relation to they'. Dengan demikian, dalam membangun kehidupan bermasyarakat di Maluku orang Maluku menerima dan memperlakukan penduduk Maluku yang berasal dari daerah lain bukan sebagai warga masyarakat yang tidak memiliki hak-hak setara dengan penduduk asli Maluku.

\section{c) Transformasi pela sebagai perjanjian (covenant)} Istilah perjanjian (covenant) yang digunakan di sini didasarkan pada dua (2) argumen. Pertama, orang yang terikat dalam hubungan pela tidak pernah menganggap ikatan hubungan itu sebagai suatu kontrak tetapi suatu 'janji'; janji untuk membangun hubungan persaudaran yang intim. Kedua, kata perjanjian memiliki pengertian teologis yang mendalam, yaitu tindakan Allah dalam Kristus untuk memperbaiki hubungan antara Allah dan manusia; hubungan antar-manusia, serta hubungan antara manusia dengan alam semesta. Dua argumen ini mengarahkan pembahasan tentang transformasi pela sebagai perjanjian.

Salah satu prinsip mendasar dari budaya pela adalah hubungan yang didasarkan atas persamaan (equality) dan mutual (mutuality). Harus diakui bahwa dalam hubungan pela tertentu ada sebutan kakak-adik, tetapi sebutan tersebut tidak dimaknai dalam pengertian hirarki apalagi superior versus inferior. Mereka 
yang tertikat hubungan pela memiliki tanggungjawab dan hak-hak yang sama. Prinsip ini juga teraplikasi dalam kehidupan keagamaan mereka. Islam Maluku dan Kristen Maluku berada pada hubungan persaudaraan yang sederajat sehingga yang satu tidak menganggap yang lain sebagai 'kafir'. Berdasarkan prinsip equality yang ada dalam budaya pela, maka pola pikir mayoritas versus minoritas yang berkembang di Indonesia sebagai salah satu pola membangun kehidupan keagamaan di Indonesia, seharusnya dikritisi bahkan ditolak oleh orang Maluku. Meskipun demikian, realitas yang teramati dalam beberapa tahun terakhir (setelah konflik sosial di Maluku) menunjukkan bahwa orang-orang Maluku cenderung mengabaikan nilai-nilai luhur yang ada dalam budaya pela. Agama selalu dikembangkan menjadi isu ketika akan berlangsung pesta demokrasi di Maluku, baik itu pemilihan kepala daerah maupun pemilihan anggota legislatif. Semangat pela yang tidak memandang agama sebagai unsur pengabaian satu terhadap lain menjadi pudar, bahkan hilang. Menghadapi realitas hidup seperti ini, budaya pela dan agama berperanan untuk mengkritisi cara pandang demikian.

Dengan melakukan perjumpaan yang kreatif antara konsep Kristus yang Disalib dengan konsep pela, orang Maluku dapat mengembangkan pemahaman yang mempengaruhi sikap mereka terhadap 'orang lain' (outsiders). Kristus yang adalah Tete Manis, sang leluhur mereka, telah mengorbankan diri untuk menghancurkan segala tembok pembatas antar-manusia termasuk tembok budaya dan agama. Prinsip teologis inilah yang antara lain ditekankan dalam teologi Paulus tentang perjanjian yang baru dalam Kristus. Berdasar pada makna pengorbanan Kristus, Paulus mengkritisi eksklusifisme identitas bangsa Israel yang cenderung mengabaikan atau mengesampaikan bangsa lain. Teologi Paulus ini mesti dikembangkan oleh orang Kristen Maluku untuk membaca dan membangun secara ulang budaya pela sehingga ketertutupan pela dapat dihilangkan.

Aspek perjanjian baru dalam Kristus yang Disalib dapat menjadi inspirasi bagi orang Kristen Maluku untuk menjadikan moment panas pela sebagai saat membarui perjanjian pela yang dulu dilakukan oleh leluhur mereka. Pembaruan perjanjian itu 
dimaksudkan agar orang Maluku tidak saja membangkitkan dan memelihara semangat persaudaraan diantara mereka tetapi juga untuk membuat ikatan perjanjian itu merangkul setiap orang yang ada di Maluku. Pemikiran ini mendorong orang Maluku untuk menghidupi pela tidak hanya sebagai suatu sikap mengingat peristiwa penting di masa lampau tetapi bahwa orang Maluku mengembangkan dan menciptakan budaya-budaya baru berdasarkan pelajaran dari warisian budaya leluhur. Dengan demikian, orang Maluku menjadi orang yang aktif membentuk sejarah hidup mereka dan bukan hanya meneruskan suatu sejarah masa lampau. Dalam semangat ini, melalui panas pela, orang Maluku dan orang Maluku yang berasal dari daerah lain (outsiders) membangun komitmen baru untuk hidup sebagai orang basodara (bersaudara). Orang Maluku menerima dan mengakui mereka yang berasal dari luar Maluku sebagai sodara (saudara) mereka, dan orang luar mengakui dan menerima bahwa Maluku adalah 'rumah mereka, tanah mereka' juga yang harus dijaga, dibangun dan dimajukan secara bersama-sama demi membangun kebersamaan hidup.

\section{Kembangkan budaya pela sebagai budaya merangkul}

Gambaran dan pembahasan terhadap proses transformasi ganda, baik terhadap konsep orang Maluku tentang Yesus maupun terhadap konsep budaya pela yang dilakukan di atas, mengarahkan upaya lanjut untuk memaknai dan mengembangkan budaya pela (maupun konsep Kristologi) secara baru, sehingga budaya pela menjadi kekuatan yang mendorong orang-orang Maluku untuk membangun pola dan gaya hidup merangkul, di mana perbedaanperbedaan dan keragaman diakui sebagai kenyataan hakiki dari kehidupan manusia.

Dalam rangka membicarakan pela sebagai budaya merangkul, berikut kutipan pernyataan Hasbulla Toisuta, seorang teolog muda Islam Maluku.

"Supaya orang Maluku dapat menerima orang luar Maluku hidup bersama membangun kehidupan bermasyarakat, orang Maluku perlu menciptakan budaya-budaya baru yang dapat 
memampukan mereka hidup dalam masyarakat majemuk. Artinya, budaya pela harus ditransformasi sehingga polanya yang hanya menghubungkan dua atau tiga negri (desa) di Maluku, diperluas menjangkau orang luar. Hal ini penting sebab kita seharusnya tidak hanya berpikir dan berbicara tentang hubungan antaragama, tetapi juga tentang hubungan antar-kelompok etnis yang telah menjadi persoalan dalam kehidupan bermasyarakat kita."

Kutipan pandangan Toisuta di atas menunjukkan kesadaran bahwa orang Maluku perlu mengembangkan pela menjadi budaya yang terbuka untuk menerima 'orang lain'. Dalam hal ini, pela yang telah ditransformasi memberi kesadaran kepada orang Kristen Maluku untuk dapat menciptakan dalam kehidupannya, ruang bagi 'yang lain' atau 'yang berbeda' itu. Kemauan untuk menciptakan ruang bagi 'orang lain' mesti merupakan kesadaran diri dari setiap orang. Oleh karena itu, setiap orang dalam masyarakat adalah pihak yang harus mengambil inisiatif untuk merangkul 'orang lain'. Dalam hal ini, budaya pela yang telah mengalami transformasi itu mendapatkan konsep baru sebagai budaya untuk berjumpa dan hidup bersama dengan 'yang lain dan berbeda' sebagai orang yang sederajat. Konsep ini tidak harus dimengerti dalam arti bahwa pihak yang dirangkul itu: 'orang lain' adalah pihak yang pasif dalam perjumpaan ini. Pihak lain itu memiliki kebebasan untuk menerima rangkulan itu atau menolaknya. Meskipun demikian, kebebasan untuk menolak tidak harus menjadi pertimbangan untuk tidak dibukanya ruang bagi 'orang lain'. Di sini, merangkul tidak berarti mewajibkan orang lain mengikuti cara hidup kita. Merangkul berarti membiarkan 'orang lain' menghidupi budayanya, agamanya, sebagaimana kita sendiri menghidupi budaya dan agama kita. Dalam hal ini, kesederajatan menjadi prinsip yang mendasari upaya membangun kebersamaan hidup, sehingga kecenderungan menguasai dan mendominasi dapat diminimalkan, bahkan dihindari dalam membangun hidup bermasyarakat.

Pengembangan budaya pela menjadi budaya merangkul akan dengan sendirinya membawa orang Maluku ke dalam situasi yang penuh resiko, sebab orang Maluku harus siap mengalami perubahan dalam 'hak-hak kultural' yang sebelumnya menjadi hak 
'yang membedakan' mereka dari 'orang luar'. Hak-hak kultural yang menempatkan mereka sebagai pihak yang memiliki kekuasaan dan kekuatan otonom 'dibagi' dengan mereka 'yang lain itu'. Ketika orang Maluku memasuki situasi berbagi hak kultural dan berbagi hidup dengan 'yang lain', tidak berarti bahwa mereka telah kehilangan budaya pela; sebaliknya nilai dasariah pela tetap dihidupi sebab orang Maluku bersedia dan siap berjumpa dengan 'yang lain' untuk hidup dalam kebersamaan. Hal ini bukan merupakan hal yang mudah. Supaya seseorang memiliki kemampuan merangkul berbagai perbedaan yang ada dalam kehidupan manusia, salah satu hal penting yang perlu dilakukan adalah orang harus dapat menempatkan diri sebagai 'orang asing' dalam budaya dan agamanya sendiri. Yang dimaksudkan dengan menempatkan diri sebagai orang asing adalah kemauan seseorang keluar dari budayanya, bahkan agamanya untuk secara berani melakukan kritik terhadap budaya dan agamanya itu. Kemauan untuk melakukan kritik diri akan membangkitkan keterbukaan untuk belajar dari budaya dan agama lain, sehingga akan terjadi perkembangan hidup. Intinya, orang harus keluar dari rasa aman dalam budaya dan agamanya untuk bertemu dengan realitas yang lain, demi pengujian terhadap zona rasa aman itu. Dengan demikian, pola hidup merangkul menuntut kesiapan menerima resiko kehilangan rasa aman seseorang, tetapi kehidupan yang dibangun dalam pola merangkul itu juga akan menyebabkan kehidupan itu menjadi proses hidup yang menyenangkan karena hidup manusia diproses secara dinamis.

Salah satu pihak yang dapat mewujudkan harapan agar budaya pela dikembangkan menjadi budaya yang merangkul adalah Gereja Protestan Maluku (GPM. Peran GPM mengembangkan pela sebagai budaya yang terbuka dan merangkul tidak dapat disangkal. Peran tersebut dapat dilakukan dengan pertama-tama, menolong warga gereja untuk menerima dan mengintegrasikan secara kritis nilai-nilai positif dan penting dari budaya pela sebagai bagian dari nilai-nilai iman Kristen. Kemudian, mengadopsi tradisi panas pela dan menjadikannya sebagai tradisi hidup bergereja dari GPM. Dengan demikian, sikap hidup beragama dan berbudaya yang 
mempertentangkan kebudayaan dengan injil dapat diatasi. Selain itu, GPM dapat berperan sebagai agen rekonsiliasi dalam mengatasi segregasi hidup secara agama maupun budaya di Maluku.

\section{Pengembangan Kristologi 'Khas' Maluku}

Dalam bagian pembahasan tentang transformasi ganda antara Kristus yang Disalib dengan budaya pela, ditemukan bahwa bagi orang Maluku, Yesus adalah Tete Manis. Sebagai Tete Manis, Yesus Kristus yang Disalib adalah Tuhan, leluhur orang Maluku yang bersedia dikorbankan untuk menghentikan segala bentuk tindakan diskriminatif yang membuat manusia hidup dalam keterpisahan dan saling menguasai.

Dengan melihat Kristus yang Disalib sebagai leluhur orang Maluku yang telah mengorbankan diri demi mengatasi problem yang dihadapi termasuk problem dalam hidup kegamaan, maka Kristus tidak diimani oleh orang Kristen Maluku sebagai Tuhan yang hanya mendamaikan dan menyelamatkan orang Kristen. Ia adalah Tuhan yang mendamaikan dan menyelamatkan semua orang, termasuk mereka yang bukan Kristen. Rekonsiliasi yang dilakukan oleh Kristus ditawarkan kepada semua orang yang hidup dalam keterasingan satu dengan yang lain. Jadi, Kristus menjembatani semua gap yang dibuat manusia, termasuk gap agama. Perspektif ini merupakan konsep yang bersumber dari perjanjian yang baru, yang menempatkan semua manusia dalam posisi yang sama dihadapan Tuhan. Konsep pertama ini mengubah kecenderungan berpikir triumphalis yang juga dijumpai dalam kehidupan orang Kristen Maluku. Dalam kerangka berpikir pela, orang Kristen Maluku tidak melihat orang Islam sebagai kafir sekalipun mereka tidak percaya kepada Yesus; demikian juga dengan orang Islam Maluku. Mereka tidak melihat orang Kristen sebagai kafir, sekalipun ajaran agama Islam tidak mengakui Yesus sebagai Tuhan. Dengan cara berpikir ini, Gereja Protestan Maluku (GPM) tidak takut untuk berbicara tentang Yesus sebagai Tuhan mereka. Dalam hal ini, GPM menumbuhkan kesadaran kebersamaan membangun kehidupan agama, tanpa menghilangkan keunikan masing-masing agama. Selain itu, GPM mesti mengkritisi cara 
pandang dan teologi Kristen yang menganggap bahwa keselamatan dalam Yesus Kristus tidak ditujukan kepada umat beragama lain. Sebab, melalui proses transformasi ganda yang telah dilakukan di atas, ditemukan bahwa budaya pela dapat menolong orang Kristen Maluku untuk menempatkan Yesus dalam posisi di mana Yesus dapat berkarya untuk keselamatan semua orang tanpa kategori batas agama dan budaya. Yesus Kristus adalah Tete Manis yang mencintai semua orang, tanpa memandang kategori etnis, budaya dan agama.

Konsep bahwa Kristus yang Disalib adalah Tete Manis, Tuhan yang mahakuasa, mendorong orang Maluku untuk tidak memperjuangkan kepentingan diri sendiri dan mengbagikan kepentingan bersama. Dalam kerangka budaya pela, orang Maluku patut mengembangkan kesadaran hidup bahwa hidup yang dibangun atas dasar kepentingan individu merupakan sikap hidup yang bertentangan dengan kehendak Tuhan, Tete Manis, karena itu adalah dosa. Pandangan ini menyumbang bagi pandangan Kristen tentang keselamatan. Keselamatan tidak akan hanya dilihat sebagai tawaran kepada orang per orang tetapi juga tawaran kepada manusia sebagai satu komunitas. Oleh karena itu, keselamatan itu tidak hanya dilihat sebagai usaha individu, tetapi juga sebagai usaha bersama sebagai masyarakat. Semua orang dalam masyarakat harus bertindak bersama-sama untuk menikmati keselamatan yang ditawarkan dalam kekinian hidup manusia. Meskipun demikian, melalui perspektif Kristus yang Disalib, orang Kristen Maluku perlu mengembangkan pandangan bahwa setiap orang memiliki tanggungjawab terhadap kehidupan sebagai masyarakat.

Sebagai Tete Manis, Kristus yang Disalib adalah Tuhan yang tinggal bersama manusia; menjadi pembimbing, penasehat dan memberi mereka kebahagiaan hidup. Pandangan ini memberi perimbangan terhadap pandangan teologi Kristen yang menempatkan Kristus dalam posisi transenden, jauh tinggi tempatnya dari manusia. Meskipun demikian, kedekatan Tuhan dengan manusia tidak berarti Yesus Kristus dapat dikontrol atau diatur oleh manusia. Yesus Kristus hidup bersama manusia tetapi Ia tetap adalah Tuhan yang memiliki otoritas dalam dirinya yang tidak 
dapat dikontrol oleh manusia. Sebagai Tete Manis, kebahagiaan yang diberikan oleh Tuhan kepada orang Maluku melampaui batasbatas agama. Oleh karena itu, orang Kristen Maluku dapat berbagi kebahagiaan mereka dengan orang Islam Maluku pada perayaanperayaan keagamaan. Bagi orang Maluku, hari-hari raya keagamaan adalah saat bergembira dan membangun kebersamaan.

Kristologi yang 'khusus' ini memiliki pengaruh yang sangat mendasar bagi gereja dalam memahami misinya. GPM dapat mengembangkan konsep bahwa misi gereja adalah misi untuk mengatasi segala bentuk pemisah yang memisahkan manusia berdasarkan segala bentuk kategori yang dibuat manusia. Selain itu, konsep pela memberi pemahaman baru dalam melakukan dan memahami misi orang Kristen dan Islam. Bahwa misi orang Kristen adalah untuk menolong orang Islam menjadi orang Islam yang baik; sebaliknya misi orang Islam adalah menolong orang Kristen menjadi orang Kristen yang baik.

\section{Daftar Acuan}

Bartels, D., Guarding The Invisible Mountain: Intervillage Alliance, Religious Syncretism and Ethnic Identity Among Ambonese Christians and Moslems in the Moluccas, Ann Arbor, Michigan: University Microfilm International, 1978.

Brinkman, M.E., The Non-Western Jesus: Jesus as Bodhisattva, Avatara, Guru, Prophet, Ancestor or Healer?, London, Oakville: Equinox, 2009.

Cooley, F., Ambonesse Adat: A General Description, New Haven, Conn: Yale University, South East Asia Studies, Cultural Report Series No. 10, 1962.

Damamain, Y.G., JOB: A narrative Approach on the Characterization and Point of View, A Dissertation Presented to the Faculty of the Southeast Asia Graduate School of Theology, Yogyakarta, 1997.

Hall., D.J., The Cross in Our Context: Jesus and the Suffering World, Minneapolis: Fortress Press, 2003.

Volf, M., Exclusion \& Embrace: A Theological Exploration of 
Identity, Otherness, and Reconciliation, Nashville: Abingdon Press, 1996.

Stassen, G.H., (eds.), Authentic Transformation: A New Vission of

Christ and Culture, Nashville; Abingdon Press, 1996.

Yee Tet-Lim N., Jews, Gentiles and Ethnic Reconciliation: Paul's

Jewish Identity and Ephesians, Cambridge:Cambridge

University Press, 2005.

\section{Ferderika Tadu :}

\section{Tanggapan Peserta}

-. Pendekatan yang dilakukan adalah kita membangun kerangka teori lalu teori ini kemudian dikembangkan di pakai untuk mengukur. Apakah bisa kita melhat konsep ibu Agustina Lumentut apa adanya lalu dikaji dari sudut pandang gender?.

-. Konsep tentang gender, menurut ibu Juberian gender adalah konstruksi yang sudah jadi tetapi dalam kenyataannya gender tidak bisa lagi dilihat sebagai konstruksi. Ada satu masa konstruksi gender laki-laki dan perempuan dapat bekerjasama tetapi disuatu masa ada juga waktunya laki-laki dan perempuan bersaing. Sejarah menunjukkan persaingan ini menimbulkan konflik. Apakah dalam desertasi itu ada pertarungan itu juga?.

-.Konsep tentang tete manis, justru ada indikasi memakai konsep tete manis justru memperkuat relasi kuasa mempertegas posisi tentang rekonsiliasi, apakah itu tidak menjadi hambatan kemudian?. Penggunaan terminologi tete manis juga bisa menjadi bagian dari teman-teman muslim?

\section{Evi Rawung:}

Pengalaman Agustin menjadi titik tolak kesadaran baru. Apakah sebenarnya yang melatarbelakangi pemikiran itu ? dan adakah pengalaman khusus dari seorang Agustina sehingga menjadi acuan untuk melakukan perubahan sosial dalam pemahaman gender dan studi feminis?. Sebab dari pemaparan tadi disebutkan bahwa acuan studi feminis dari pengalaman perempuan itu sendiri. Kalau 
seorang Agustina sudah melakukan perubahan sosial di pegunungan Sulawesi Tengah, apa indikator perubahan itu.

\section{Evy Pada}

Presentasi ini menghilangkan ketakutan bahwa penelitian studi doktor itu berat dan susah tetapi setelah mengikuti presentasi kedua ibu ini membuat kita enjoy dan tidak perlu takut. Dari presentasi ibu Juberlian, ternyata semangat Agustina menjadi inspirasi yang kuat dan saya menangkap pesan semua positif saja. Sebagai seorang akademisi yang berpikir secara objektif, saya mau melihat apakah ada sisi negatif dari pengalaman hidupnya. Supaya kita bisa belajar bukan hanya dari hal yang positif tetapi hal yang negatif juga perlu. Karena mungkin masih ada ibu-ibu lain yang juga berkembang pada waktu itu. 
122 